\title{
Influence of Sea Ice Treatment in a Regional Climate Model on Boundary Layer Values in the Fram Strait Region
}

\author{
Tido Semmler and Daniela JacoB \\ Max Planck Institute for Meteorology, Hamburg, Germany \\ K. HeINKE SCHLÜNZEN \\ Meteorological Institute, University of Hamburg, Hamburg, Germany \\ RALF PODZUN \\ Max Planck Institute for Meteorology, Hamburg, Germany
}

(Manuscript received 15 January 2003, in final form 10 September 2003)

ABSTRACT

\begin{abstract}
The influence of two simple descriptions for the sea ice distribution on boundary layer values is investigated by comparing model results from the regional climate model REMO with measured data in the Fram Strait in April 1999. One method for determining the sea ice distribution in REMO is to diagnose the sea ice cover from the prescribed surface temperature and allow each grid cell to be either completely free of ice or completely covered by ice (REMO-original). The other one is to employ a partial sea ice concentration in each REMO grid cell with the input data derived from satellite data (REMO-partial). Surface fluxes are average values of the ice and water partial fluxes. There is a clearly better agreement between measured and simulated surface and boundary layer temperatures and humidities when using REMO-partial compared to REMO-original. The closed ice cover in REMO-original leads to downward sensible heat fluxes over ice, whereas the ice cover with leads and polynyas in REMO-partial leads to smaller downward or even upward sensible heat fluxes. The introduction of the partial sea ice concentration smoothes unrealistically sharp gradients between ice-covered and ice-free regions. which can influence cloud cover and precipitation. An additional result of the study is that the simulation of the albedo could be improved in allowing a larger range of sea ice albedos and introducing a water albedo dependent on sun zenith angle.
\end{abstract}

\section{Introduction}

In the Arctic region the distribution of sea ice is an important climatic factor. Because of the insulating effect of sea ice and the contrast between the albedo of sea ice and open water, strong temperature gradients and mesoscale meteorological phenomena like polar lows can be observed close to the ice edge (Grønås and Kvamst $\varnothing$ 1995).

The influence of the sea ice distribution on boundary layer values has already been investigated with different methods. Simmonds and Budd (1991) studied the influence of leads on surface temperature, turbulent heat fluxes, sea level pressure, and precipitation with a general circulation model in idealized studies. They calculated the investigated parameters for a closed sea ice cover and four different fractions of open water in the whole

Corresponding author address: Dr. Tido Semmler, Max Planck Institute for Meteorology, Bundesstrasse 55, D-20146 Hamburg, Germany.

E-mail: semmler@dkrz.de sea ice area around Antarctica. They found a monotone increase of surface temperature and turbulent heat fluxes with increasing open-water fraction, with the strongest changes occuring at low open-water fractions. For the sea level pressure and precipitation the changes are not so clear, although there is a tendency toward reduced sea level pressure over mixed sea ice and water compared with closed sea ice. Rinke and Dethloff (2000) used the regional climate model HIRHAM in a horizontal resolution of $55 \mathrm{~km}$ to study the influence of the lateral and lower boundary values and the initialization on the simulated Arctic atmosphere. They found that because of the heat flux through the ice the assumed sea ice thickness plays an important role for the simulation of the ice surface temperature, which also influences the sea level pressure. Even models with finer horizontal and vertical resolutions (scale of $100 \mathrm{~m}$ to 1 $\mathrm{km}$ in the horizontal and $10 \mathrm{~m}$ in the vertical) have been applied to look at the impacts of leads and polynyas on turbulent fluxes and cloud cover (Burk et al. 1997; Mailhot et al. 2002; Glendening and Burk 1992). The main 
conclusions from these studies are that higher wind speeds lead to stronger upward turbulent heat fluxes and that large updraft velocities, turbulence, and clouds occur downwind from the leads. Aircraft observations taken over leads and polynyas during the Arctic Cloud Experiment have shown that the turbulent sensible heat flux over open water can be responsible for up to $34 \%$ of the sum of Arctic surface energy fluxes during April (Gultepe et al. 2003).

Yet there is no detailed comparison of simulated boundary values dependent on the prescribed sea ice distribution between models and measurements. Most of the studies are pure observational studies or use idealized model simulations. Since it has been shown in all above-mentioned studies that there is a large influence of leads and polynyas on the boundary layer, it is necessary to investigate how precise the sea ice is prescribed in numerical weather and climate simulations and how large the errors can be if the sea ice concentration is prescribed in a simplified way. The studies are performed with the three-dimensional, hydrostatic, regional, atmospheric climate model REMO (Jacob and Podzun 1997; Jacob 2001) using a high horizontal resolution of $18 \mathrm{~km}$.

Within the comprehensive field campaign Fram Strait Cyclone Experiment (FRAMZY), which took place from 3 to 24 April 1999 in the Fram Strait and Greenland Sea region (Brümmer et al. 2001), there were five flight missions on 10,12, 14, 18, and 19 April. The aircraft observations are used to validate REMO with two different methods to consider sea ice distributions. The sea ice distribution is either diagnosed from the prescribed surface temperature (REMO-original) or derived from satellite data (REMO-partial). In REMO-original each grid cell is only allowed to be either completely free of ice or completely covered by ice, whereas there is a partial sea ice cover for each grid cell in REMO-partial. A detailed comparison of both model simulations with the observations has been carried out.

In section 2 a short description of REMO is given. The experimental setup including the two different ways of the sea ice treatment in the model is described in section 3. Section 4 deals with the validation of the simulations of the boundary layer close to the ice edge with aircraft observations. In section 5 the influence of the sea ice distribution on the boundary layer is discussed. In section 6 conclusions and an outlook are given.

\section{The regional climate model REMO}

Here a short summary of the main features of REMO is given. The model characteristics are described in more detail in Jacob (2001) and Jacob et al. (2001). REMO is based on the Europa-Modell of the German Weather Service (Majewski 1991). It can be alternatively used with the physical parameterizations of the Europa-Modell or with the parameterizations of the global climate model ECHAM-4 (Roeckner et al. 1996). The dynamical core of the model as well as the discretization in space and time are based on the Europa-Modell. However, in REMO with ECHAM-4 physics, temperature, water vapor, and liquid water are prognostic variables, not enthalpy and total water content. In the present study REMO with ECHAM-4 physics is applied. Therefore, the model description will concentrate on this parameterization package.

In addition to temperature, water vapor, and liquid water, the horizontal wind components and surface pressure are prognostic variables in REMO. To avoid largely different extensions of the grid cells in polar regions, REMO uses a rotated grid with the equator of the rotated system in the middle of the model domain. The vertical coordinate is defined by a hybrid system following the orography near the surface and following the pressure levels above $50 \mathrm{hPa}$. The horizontal discretization is done on the Arakawa $\mathrm{C}$ grid; the vertical discretization is based on Simmons and Burridge (1981). For the discretization in time, the leapfrog scheme is used. For smoothing, the Asselin filter technique is applied.

A regional model has to be initialized at the first time step and supplied with lower and lateral boundary values during the whole simulation. The initialization is done for all prognostic variables at all model levels. In addition, surface temperature, soil temperatures for five soil layers down to a depth of $10 \mathrm{~m}$, soil moisture, snow depth, and temperature, as well as the skin reservoir content (water stored by the skin of the vegetation), must be supplied for initialization.

As lower boundary values, sea surface temperature and sea ice distribution are prescribed during the whole model simulation. In this study two different methods are used to prescribe the sea ice distribution. These methods are discussed in section 3. For land grid points the orography, the roughness length, the soil texture, the albedo of the soil, and some vegetation parameters like vegetation ratio, forest ratio, leaf area index, and field capacity of soil are needed as lower boundary values. The lateral boundary values consist of all prognostic variables except for liquid water and they influence the outer eight rows of the model area. At the upper boundary a radiative boundary condition according to Klemp and Durran (1983) and Bougeault (1983) is applied.

The following parameterization schemes are used in REMO with ECHAM-4 physics: The radiation parameterization is adopted from the European Centre for Medium-Range Weather Forecast (ECMWF) model (Fouquart and Bonnel 1980; Morcrette and Fouquart 1986), with only a few changes described in Roeckner et al. (1996).

Clouds are divided into stratiform and convective clouds. The liquid water content of stratiform clouds is determined by the corresponding budget equation including sources and sinks due to phase changes and precipitation. An empirical, temperature-dependent 
function is used to determine the cloud ice content; thus, influences on the radiation are included. The parameterization of the convective clouds is based on the mass flux concept from Tiedtke (1989) with changes in deep convection. For deep convection, an adjustment closure according to Nordeng (1994) is used.

Soil temperatures on land are calculated from diffusion equations solved in five different layers covering the uppermost $10 \mathrm{~m}$ of the soil. For the soil hydrology three different budget equations for the amount of snow, the water intercepted by vegetation, and the soil water content are applied.

Like the land surface temperature, the surface temperature of the sea ice is determined from the residuum of the heat and radiation fluxes at the surface. For the calculation of the conductive heat flux through the ice, a constant ice thickness of $2 \mathrm{~m}$ is assumed. Snow on sea ice is not explicitly considered but is indirectly accounted for by the sea ice albedo. The sea ice albedo is assumed to be between $55 \%$ for a surface temperature of $0^{\circ} \mathrm{C}$ and $75 \%$ for a surface temperature of $-10^{\circ} \mathrm{C}$ or below.

The turbulent heat and momentum fluxes at the surface are determined according to the Monin-Obhukov theory (Hennemuth and Jacob 2002):

$$
\begin{aligned}
H & =\rho \cdot c_{p} \cdot C_{H} \cdot u_{z} \cdot \Delta \Theta, \\
E & =\rho \cdot \lambda \cdot C_{E} \cdot u_{z} \cdot \Delta q, \\
\tau & =\rho \cdot C_{D} \cdot \Delta u^{2}
\end{aligned}
$$

where $H$ is the sensible heat flux, $E$ the latent heat flux, and $\tau$ the momentum flux at the surface; $\Delta \Theta, \Delta q$, and $\Delta u$ are the differences in potential temperature, specific humidity, and horizontal wind speed between the lowest model level at about $70 \mathrm{~m}$ and the surface; $u_{z}$ represents the wind speed in the lowest model level, $\rho$ the air density, $c_{p}$ the specific heat capacity of air at constant pressure, and $\lambda$ the latent heat of evaporation. The calculation of the transfer coefficients $C_{H}, C_{E}$, and $C_{D}$ is described in Hennemuth and Jacob (2002).

An important variable for calculating the transfer coefficients is the surface roughness length. Over land, the surface roughness length is influenced by vegetation and the variance of the orography within one model grid cell. Over sea, the Charnock formula

$$
z_{0}=\frac{\alpha \cdot u_{*}^{2}}{g}
$$

is applied, with $z_{0}$ being the surface roughness length for momentum. $u_{*}$ the friction velocity, $g$ the acceleration due to gravity, and $\alpha$ an empirical factor. Thus higher wind speeds lead to higher surface roughness lengths for momentum due to surge. The roughness lengths for heat and water vapor over sea are determined as

$$
z_{H}=z_{0} \exp \left(2-86.276 \cdot z_{0}^{0.375}\right) .
$$

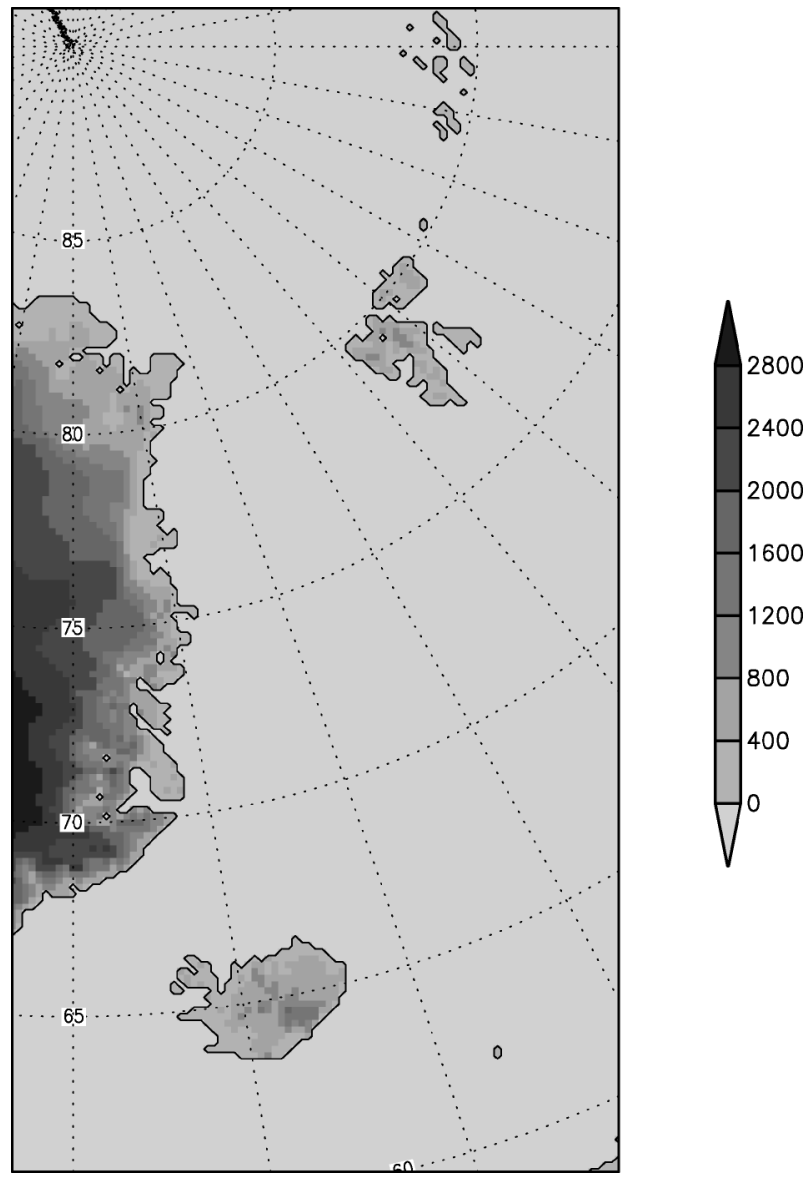

FIG. 1. Orography $(m)$ in the simulation domain.

Over sea ice, the surface roughness length is set to a constant value of $1 \mathrm{~mm}$. This is a kind of average value over all types of sea ice. The surface roughness length of sea ice can vary from 0.06 to $10 \mathrm{~mm}$ (Repina and Smirnov 2000).

\section{Experimental setup}

The FRAMZY period (3 to 24 April 1999) has been simulated with REMO in an area including the east of Greenland, Spitsbergen, Iceland, and the Fram Strait (Fig. 1) in a horizontal resolution of $18 \mathrm{~km}$ and with 20 vertical layers. For initialization and lateral forcing of the model, analyses of the ECMWF are used. The orography is taken from the high-resolution dataset GTOPO30 (USGS-NASA 2002) and the vegetation parameters from a global land surface dataset of Hagemann et al. (1999).

In REMO-original the sea ice distribution is diagnosed from the prescribed sea surface temperature. If the sea surface temperature in a grid cell is below the freezing point of seawater, which is assumed to be $-1.79^{\circ} \mathrm{C}$ for an average salinity, the whole grid cell is assumed to be covered by sea ice. Otherwise no sea ice 
a)

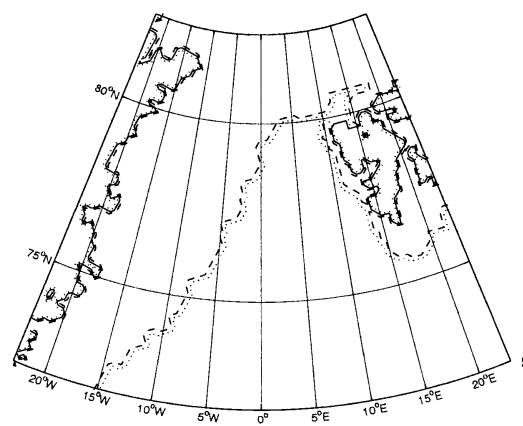

b)

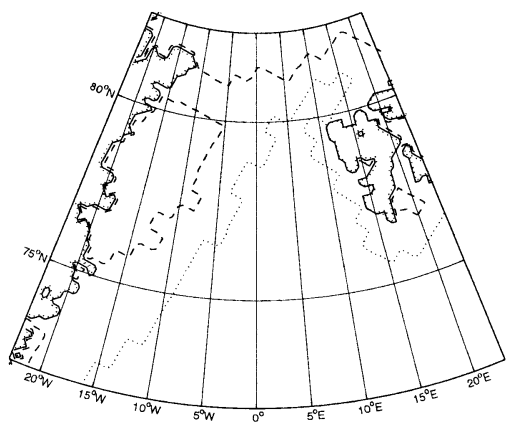

c)

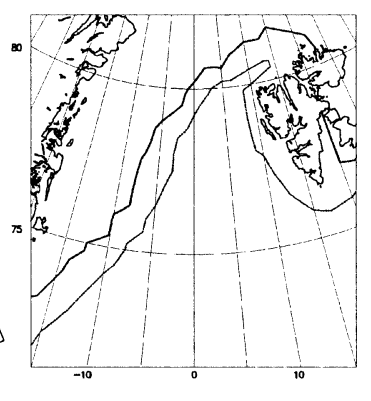

FIG. 2. Sea ice concentration (\%) from (a) REMO-original, (b) REMO-partial, and (c) observations of the Norwegian Meteorological Institute on 20 Apr 1999. In the model results, the dotted line indicates $10 \%$ and the dashed line $90 \%$ sea ice concentration; in the observations, the thin line indicates $10 \%$ and the thick line $90 \%$.

will be assigned to the grid cell. For the determination of the sea ice concentration in REMO-partial satellite data are taken into account. Daily data from the Special Sensor Microwave Imager (SSM/I) of the satellite F13 of the Defense Meteorological Satellite Program (DMSP) are used.

The sea ice concentration from SSM/I is calculated according to the algorithm developed by the National Aeronautics and Space Administration (NASA) (Cavalieri et al. 1992) using different brightness temperatures. Unrealistic sea ice resulting from atmospheric water vapor, cloud liquid water, rain, or wind-induced roughness of the sea surface is removed using a weather filter. At the coastline the brightness of the sea bottom is another problem leading to an unrealistic sea ice concentration. After interpolating the sea ice concentration to the REMO grid this problem is widely solved in setting the sea ice concentration to 0 in all grid cells with a prescribed sea surface temperature of more than $1^{\circ} \mathrm{C}$. This simple method can lead to errors because small amounts of sea ice can still exist if the sea surface temperature is more than $1{ }^{\circ} \mathrm{C}$. For this study the method is sufficient because we focus on the effects of small water portions in a nearly closed sea ice cover on boundary layer values and not on areas with low sea ice concentrations.

In REMO-partial there can be land, water, and sea ice in one grid cell. For grid cells containing more than one surface type, the surface radiation, heat, moisture, and momentum fluxes are calculated separately for each surface type. This is done according to Avissar and Pielke (1989). For calculating the effects of the fluxes on temperature and humidity in the lowest model level the surface fluxes are averaged over the three different surface types weighted by the fractional area of each surface type. This method is similar to the blending height concept described by von Salzen et al. (1996).

\section{Validation of REMO}

Two different REMO simulations have been conducted for the FRAMZY period to study the influence of the sea ice treatment on the quality of the REMO results and the influence of the sea ice distribution on surface energy and moisture fluxes, on precipitation, and on the development of cyclones. In Figs. $2 \mathrm{a}$ and $2 \mathrm{~b}$ the two sea ice distributions used in REMO are given in comparison with observations from the Norwegian Meteorological Institute (Fig. 2c) for 20 April 1999. The ice edge in REMO-original (Fig. 2a) is rather abrupt because the sea ice concentration is only allowed to be $0 \%$ or $100 \%$ in this version. The ice edge in REMOoriginal is placed between the $10 \%$ and the $90 \%$ isolines of the observed sea ice concentration. The position and the shape of the ice edge in REMO-partial (Fig. 2b) and in the observations (Fig. 2c) agree quite well, although because of the horizontal resolution of $25 \mathrm{~km}$ of the satellite-derived sea ice concentrations, the ice edge in REMO-partial is a bit smoother than observed. Thus the horizontal resolution of the sea ice data is coarser than the resolution used in the REMO simulations. The total ice area is similar in both REMO simulations, but the distribution is different. The amount of ice is lower in REMO-partial.

On 19 April 1999 a cyclone crossed the ice edge from south to north. The track of the cyclone is shown in Fig. 3 for 17-20 April. The tracks derived from ECMWF analysis data, and results from both REMO simulations are similar, with the tracks of both REMO simulations being more similar to each other than to the ECMWF analysis. In both REMO simulations the low pressure system is intensified compared with the ECMWF analysis, which is probably a result of the higher resolution of REMO. Coarse resolutions prevent the development of cyclones with strong pressure gradients (Walsh and Katzfey 2000; Katzfey 1999). There are enhanced gradients in the REMO simulations of the sea level pressure, the temperature at $850 \mathrm{hPa}$, and the geopotential height at $500 \mathrm{hPa}$, compared with the analyses. As an example, the geopotential heights at $500 \mathrm{hPa}$ from the ECMWF analysis and both REMO simulations are presented in Fig. 4. All in all the large-scale structure is well represented in both REMO simulations. 
a)

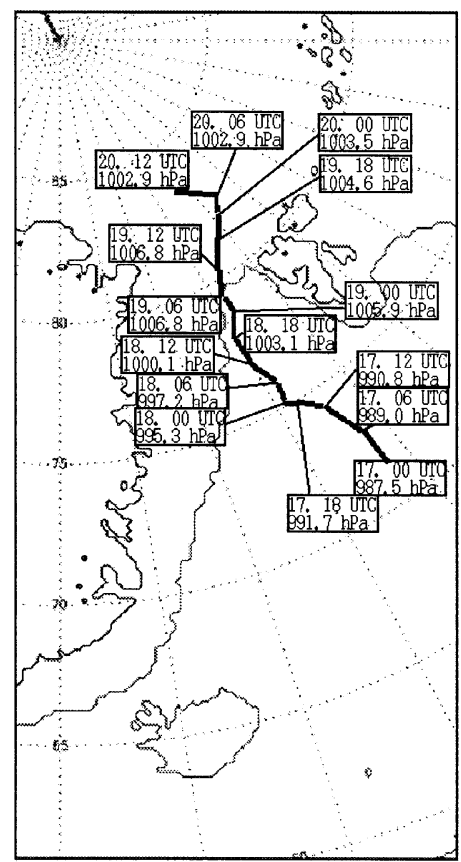

FIG. 3. Cyclone track from (a) ECMWF analyses, (b) REMO-original, and (c) REMO-partial for the period 17-20 Apr 1999.

c)
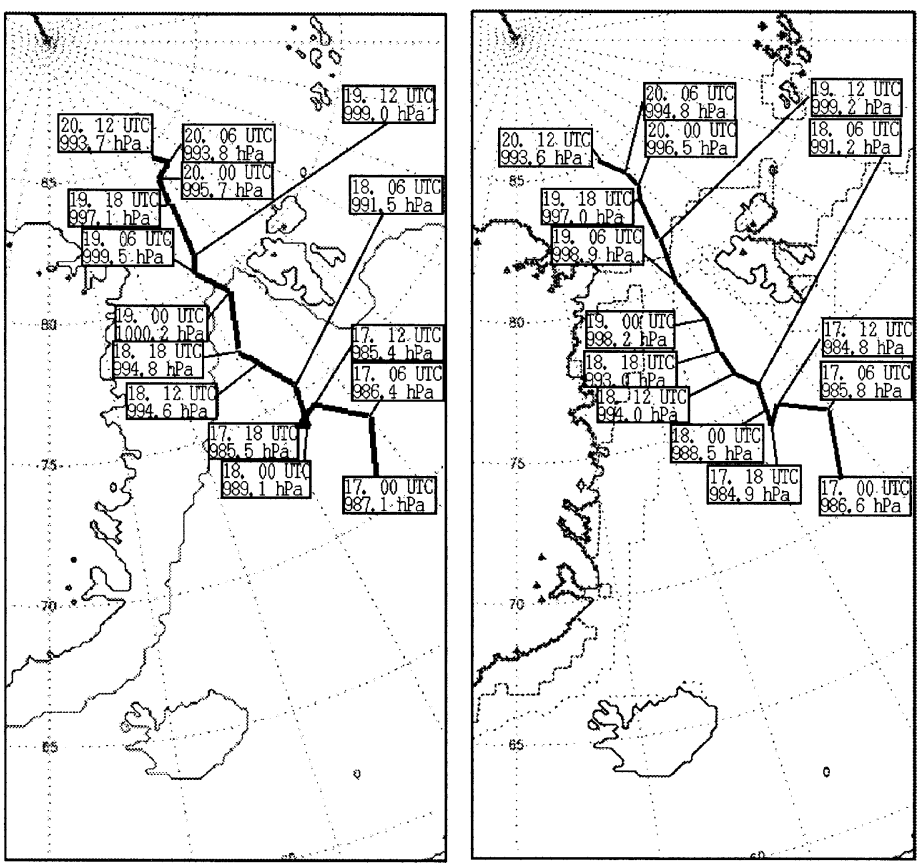

a)

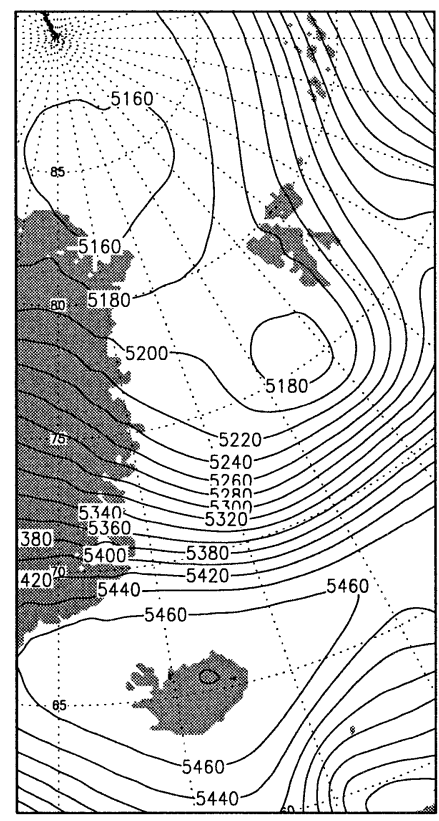

b)

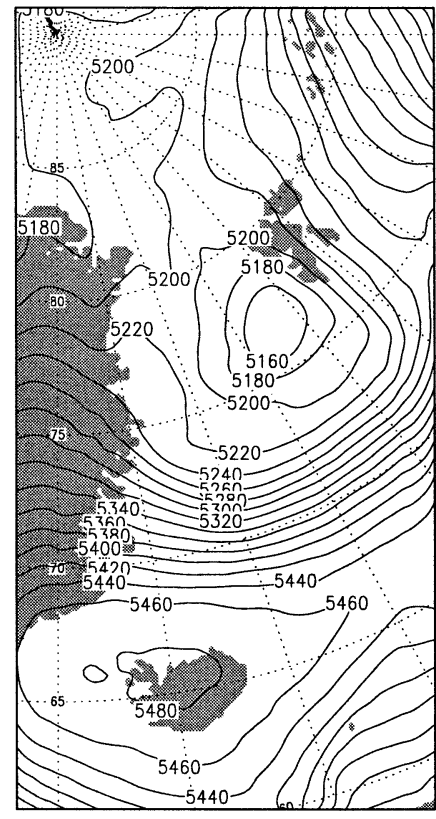

c)

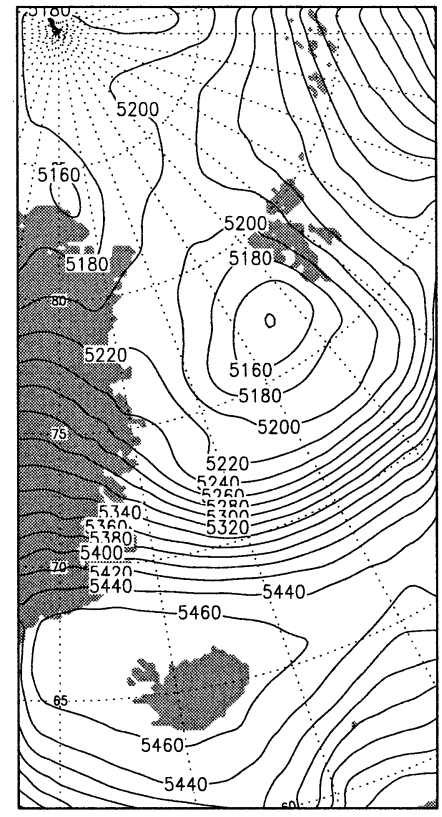

FIG. 4. Geopotential height [geopotential meters (gpm)] at $500 \mathrm{hPa}$ in (a) the ECMWF analyses, (b) REMO-original, and (c) REMO-partial for 0600 UTC 20 Apr 1999. 
a)

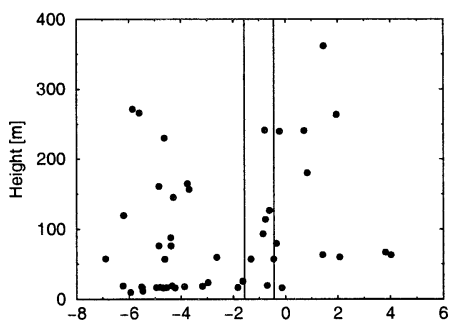

b)

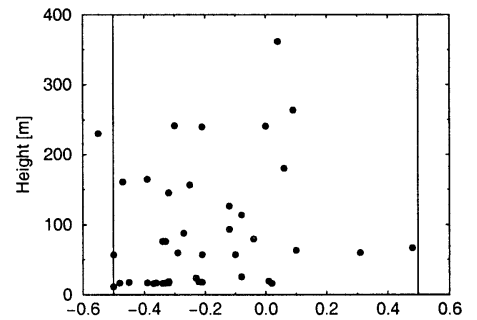

c)

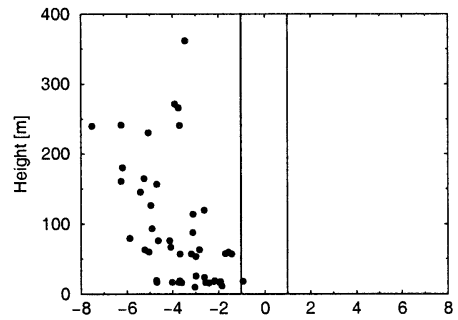

FIG. 5. Differences of (a) temperature (K), (b) specific humidity $\left(\mathrm{g} \mathrm{kg}^{-1}\right)$, and (c) wind speed $\left(\mathrm{m} \mathrm{s}^{-1}\right)$ between REMO-original results and measurements as a function of flight height. The vertical lines indicate the errors of the measurements.

To perform a detailed comparison for all horizontal flights, the meteorological parameters, the flight height, and the geographical coordinates of the aircraft have been averaged over $180 \mathrm{~s}$. The aircraft has reached a speed of about $100 \mathrm{~m} \mathrm{~s}^{-1}$. Thus in $180 \mathrm{~s}$ the aircraft traveled about $18 \mathrm{~km}$, which is the size of a REMO grid cell. With this integration meteorological phenomena of the same spatial scale are compared, but average values over a line are compared with average values over a volume. The same is valid for the time scale, because the model is used with a time step of $120 \mathrm{~s}$, which is close to the averaging interval of $180 \mathrm{~s}$.

The REMO results are interpolated linearly in time and space to the aircraft observations. The spatial interpolation for heat, momentum, and radiation fluxes is done two-dimensionally because these fluxes are assumed to be representative for the surface. The fluxes are only compared for flight heights less than $100 \mathrm{~m}$. The spatial interpolation for temperature, specific humidity, and wind speed is done three-dimensionally. In the near-surface heights below $70 \mathrm{~m}$ (lowest model level) a nonlinear vertical interpolation is used. Vertical profiles according to the theory of Monin-Obhukov are assumed in this case (Majewski et al. 1995).

To avoid a comparison of the meteorological parameters above very different sea ice distributions, the comparison considers only those data for which the sea ice concentration observed by the aircraft during an $18-\mathrm{km}$ long flight track and the corresponding one interpolated from REMO are larger than $80 \%$. The aircraft traveled mainly over ice-covered regions; therefore, high sea ice concentrations are mostly found. The meteorological parameters are again weighted averages over the sea ice part and the water part of each flight track and the corresponding REMO-partial grid cells. In REMO-original the meteorological parameters are always representative for sea ice.

\section{a. Boundary layer values}

Figures 5 and 6 show the differences of (a) measured and simulated temperature, (b) specific humidity, and (c) wind speed for both REMO simulations as a function of height. In Table 1 the means, standard deviations, biases, root-mean-square errors (rmse), and coefficients of correlation are calculated for the aircraft observations and both REMO simulations. Different values for the observations are given in the comparison with REMOoriginal and REMO-partial because the comparison criterion of sea ice concentrations of more than $80 \%$ in the simulation and in the observation is fulfilled on slightly different parts of the flight tracks because of different sea ice concentrations in the corresponding REMO grid cells.

The deviations in temperature are between -7 and $+4 \mathrm{~K}$ in REMO-original and -4 and $+3 \mathrm{~K}$ in REMOpartial. Thus in both simulations most temperature deviations are larger than the error of the measurements a)

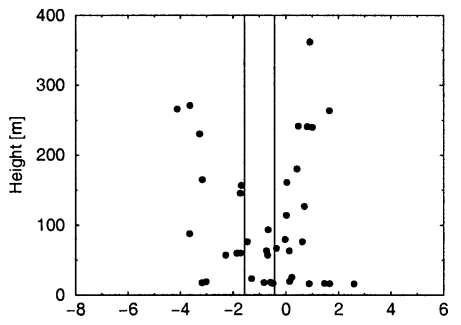

b)

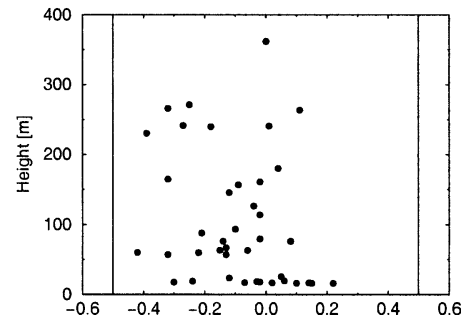

c)

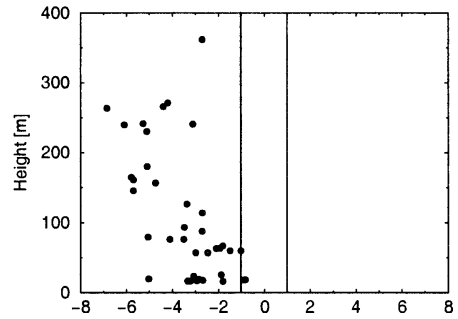

FIG. 6. Same as Fig. 5, but for REMO-partial results minus measurements. 
TABLE 1. Statistics of temperature, specific humidity, and wind speed in the aircraft measurements compared with both REMO simulations.

\begin{tabular}{|c|c|c|c|c|}
\hline & \multicolumn{2}{|c|}{ REMO-original } & \multicolumn{2}{|c|}{ REMO-partial } \\
\hline & Aircraft & REMO & Aircraft & REMO \\
\hline \multicolumn{5}{|c|}{ Temperature $\left({ }^{\circ} \mathrm{C}\right)$} \\
\hline Mean & -13.3 & -16.0 & -14.0 & -14.6 \\
\hline Std dev & 2.5 & 3.1 & 2.1 & 1.9 \\
\hline Bias & & -2.7 & & -0.6 \\
\hline Rmse & & 4.0 & & 1.8 \\
\hline Correlation & & 0.48 & & 0.66 \\
\hline \multicolumn{5}{|c|}{ Specific humidity $\left(\mathrm{g} \mathrm{kg}^{-1}\right)$} \\
\hline Mean & 1.19 & 0.92 & 1.11 & 1.02 \\
\hline Std dev & 0.31 & 0.38 & 0.25 & 0.20 \\
\hline Bias & & -0.27 & & -0.09 \\
\hline Rmse & & 0.42 & & 0.18 \\
\hline Correlation & & 0.60 & & 0.79 \\
\hline \multicolumn{5}{|c|}{ Wind speed $\left(\mathrm{m} \mathrm{s}^{-1}\right)$} \\
\hline Mean & 14.0 & 10.2 & 14.2 & 10.7 \\
\hline Std dev & 4.0 & 3.6 & 4.4 & 3.9 \\
\hline Bias & & -3.8 & & -3.5 \\
\hline Rmse & & 4.1 & & 3.8 \\
\hline Correlation & & 0.92 & & 0.94 \\
\hline
\end{tabular}

according to Brümmer et al. (2000). The bias and rmse are reduced by more than $50 \%$, and the coefficient of correlation is increased in REMO-partial compared with REMO-original. In REMO-partial all deviations in specific humidity are smaller than the measurement error, which is very large for the very low specific humidities well below $1 \mathrm{~g} \mathrm{~kg}^{-1}$. There is at least one outlier in REMO-original. Again in REMO-partial, bias and rmse are reduced by more than $50 \%$, and the coefficient of correlation is increased in REMO-partial compared with REMO-original. The wind speed is clearly underestimated in both REMO simulations by $1-8 \mathrm{~m} \mathrm{~s}^{-1}$. The larger deviations can be found in higher altitudes. If while looking at relative deviations there is no clear height dependence, it is because the wind speed is larger in higher altitudes compared to the values near the surface. The mean relative underestimation of wind speed is about $25 \%$. Bias, rmse, and the coefficient of correlation are only slightly improved in REMO-partial compared with REMO-original (Table 1).

\section{b. Surface values}

Figures 7 and 8 show the measured and simulated values for the heat, momentum, and radiation fluxes and the surface temperature for both REMO simulations as average values for one flight mission, respectively. The turbulent fluxes measured on 18 and 19 April are problematic because on these days the aircraft has flown more than $50 \mathrm{~m}$ above the surface, in most cases because of bad weather conditions. In REMO the turbulent fluxes are determined by the gradient approach. For example, for the calculation of the momentum flux the wind speed in the lowest model level, which is located about $70 \mathrm{~m}$ above the surface, is used. Thus the momentum flux is representative for a height between 0 and $35 \mathrm{~m}$. From the aircraft measurements the momentum flux is determined from the correlation product $\overline{w^{\prime} u^{\prime}}$ ( $w$ being the vertical velocity, $u$ the horizontal velocity, an overbar representing the mean, and a prime representing the deviation from the mean) in the flight height. The analog is valid for the turbulent heat fluxes. On 10, 12, and 14 April, the aircraft has flown between 15 and $50 \mathrm{~m}$ above the surface. Thus on these days the measurements are somewhat comparable with the simulation in contrast to the ones of 18 and 19 April, where the measurements will indicate smaller turbulent fluxes than near the surface. Furthermore, the measured radiation fluxes on 18 and 19 April may be not representative of the surface because the aircraft has flown through clouds on these days. Thus in the calculation of the statistics for the heat, momentum and radiation fluxes, and the surface temperature, only the 10,12, and 14 April data are considered (Table 2).

Whereas in REMO-original the sensible (Fig. 7a) and the latent (Fig. 7b) heat fluxes are close to 0 because of the closed sea ice cover, there are strongly upwarddirected heat fluxes in REMO-partial (Figs. 8a and 8b). The truth is in between. Because of the relatively coarse resolution of the sea ice concentrations, their gradient is weaker in REMO-partial than in the aircraft observations. If considering all flight tracks and grid cells with more than $80 \%$ sea ice coverage, the ice concentration is exactly $100 \%$ in REMO-original, about $99 \%$ in the aircraft measurements, and only about $90 \%$ in REMO-partial. This shows that the prescribed sea ice concentration from satellite data is much lower than the one observed from the aircraft. The results support findings of Simmonds and Budd (1991) that the largest changes in the turbulent heat fluxes occur at low openwater fractions. Even $1 \%$ open water is sufficient to lead to upward-directed turbulent heat fluxes instead of heat fluxes close to 0 . Whereas the absolute values of the bias and rmse for the turbulent heat fluxes are mostly higher in REMO-partial than in REMO-original because of the higher absolute values of the fluxes in REMOpartial (Table 2), the coefficients of correlation are slightly improved for the latent heat flux in REMOpartial compared with REMO-original. Also, the standard deviations of latent heat fluxes are better represented in REMO-partial than in REMO-original compared with the observations.

The simulated momentum fluxes (Figs. 7c and 8c) are similar for both REMO simulations. In most cases the differences to the measurements are smaller than the error of the measurements. On 10 April both REMO simulations tend to underestimate the momentum fluxes, and on 19 April they tend to overestimate them. The underestimation of the momentum fluxes on 10 April is consistent with the systematically underestimated wind speed; the overestimation on 19 April is probably due to the larger flight height on this day, where the 
a)

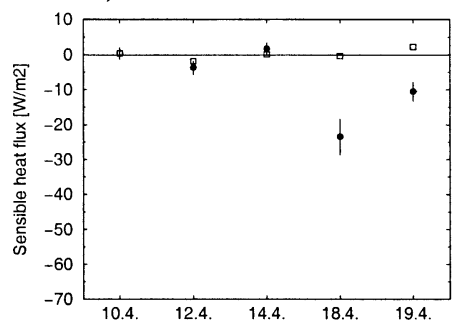

d)

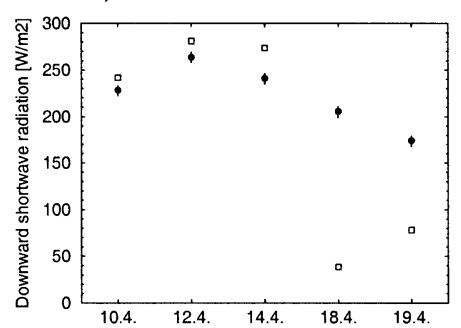

g)

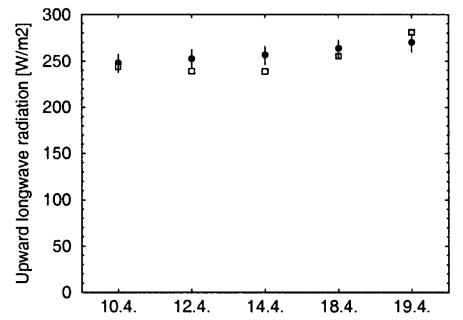

b)

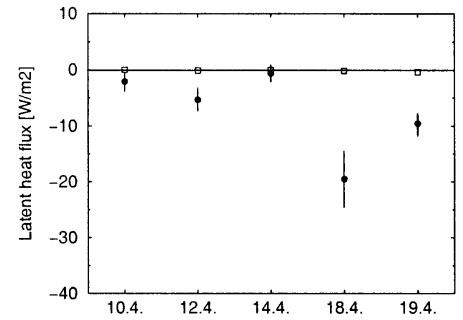

e)

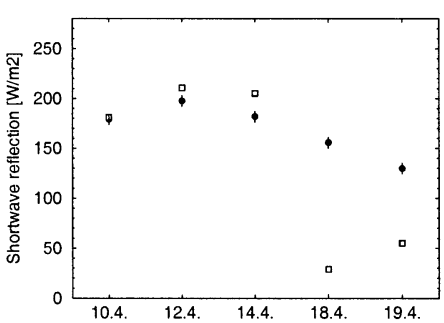

h)

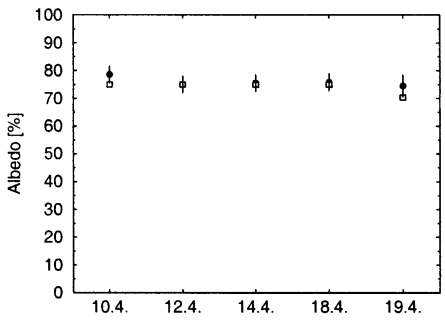

c)

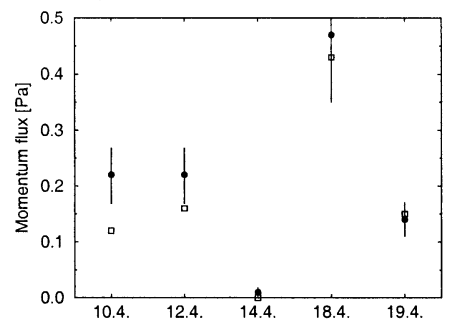

f)

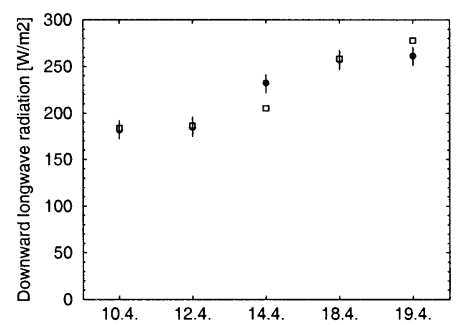

i)

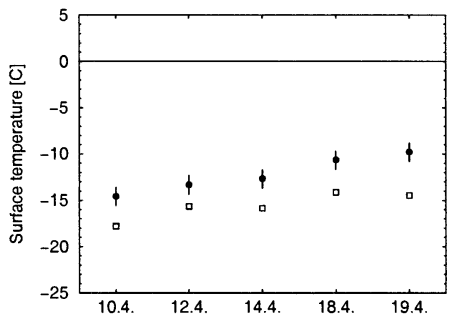

FIG. 7. Average values of the (a) sensible heat fluxes, (b) latent heat fluxes, (c) momentum fluxes, (d)-(g) radiation fluxes, (h) albedos, and (i) surface temperatures over all measurements below $100 \mathrm{~m}$ (dots with error bars) and the corresponding REMO-original results (squares) for each flight mission. The turbulent heat fluxes are defined positive downward and negative upward.

momentum fluxes are smaller than near the surface. Bias and rmse are improved in REMO-partial compared with REMO-original, whereas the coefficient of correlation is smaller in REMO-partial than in REMO-original (Table 2).

In REMO-partial the influence of changed roughness lengths due to scattered water and ice portions within one grid cell cannot be considered because the turbulent fluxes are calculated for each surface type and its roughness length separately. In marginal sea ice zones this method could lead to an underestimation of the fluxes because such a surface is generally more structured than pure water or pure sea ice. But also a closed sea ice cover with hummocks can have large surface roughness lengths up to $10 \mathrm{~mm}$ (Repina and Smirnov 2000), which is considered in REMO by using an average ice surface roughness length of $1 \mathrm{~mm}$. On the other hand, over the water part of the grid cell the roughness due to surge could be overestimated because the surge is hindered by sea ice in the water. There is probably no systematic error by this approach because the local effect of increased (sea ice) or decreased (water) roughness lengths on the grid-averaged fluxes depends on the fraction of ice in the grid cell.

In REMO-original the downward shortwave radiation is overestimated on 10, 12, and 14 April (Fig. 7d), whereas it is underestimated in REMO-partial on these days (Fig. 8d). Although on 18 and 19 April there was a closed and sometimes multilayer cloud cover, whereas on 10, 12, and 14 April it was often cloudless or only partly cloudy, the shortwave radiation measurements only show a small difference between the nearly cloudless and the cloudy days, while both REMO simulations do show a pronounced difference. The measurements on 18 and 19 April seem to be influenced by horizontal radiative effects caused by the clouds on these days. 
a)

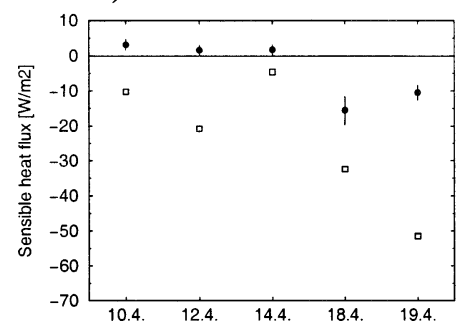

d)

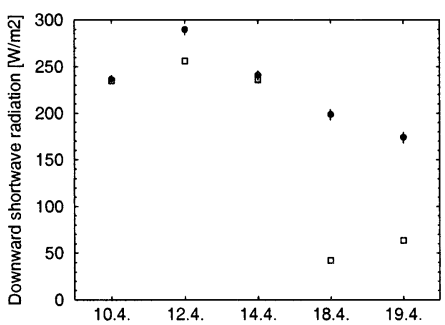

g)

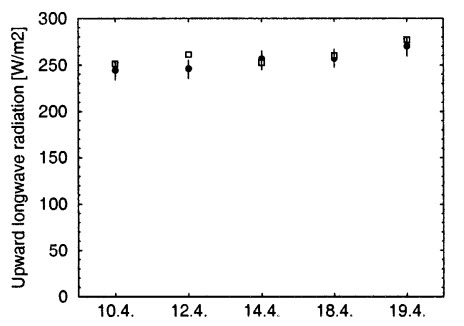

b)

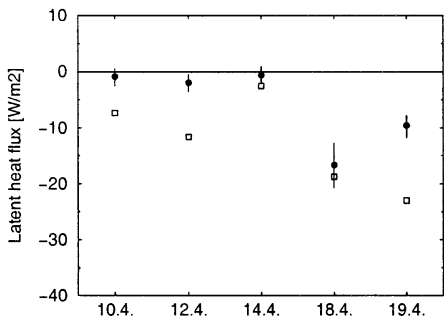

e)

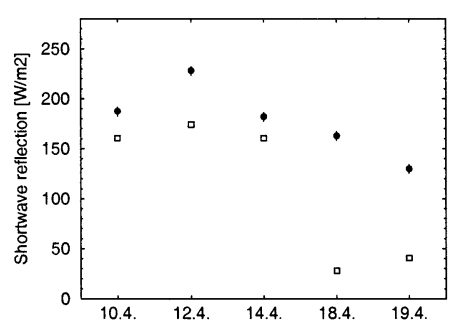

h)

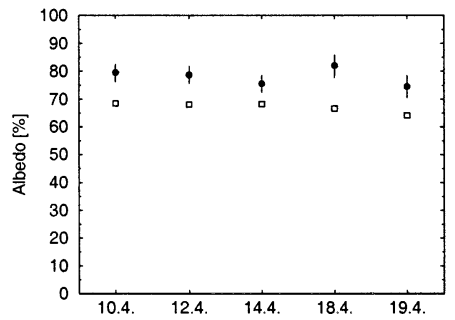

c)

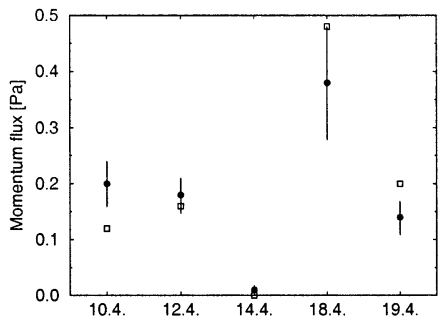

f)

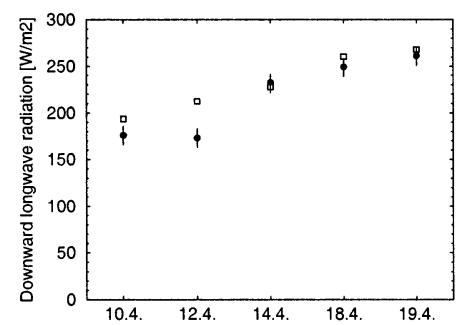

i)

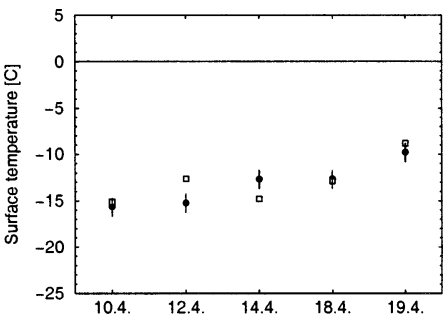

FIG. 8. Same as Fig. 7, but for REMO-partial results.

Thus an interpretation of the comparison of the shortwave radiation fluxes is only possible for the 10, 12, and 14 April. The difference between REMO-original and REMO-partial on these days is probably a result of the increased moisture in REMO-partial compared with REMO-original. Because the albedo is realistically represented in REMO-original (Fig. 7h), the shortwave reflection (Fig. 7e) is overestimated by as much as the downward shortwave radiation in REMO-original. In REMO-partial the underestimation of the albedo (Fig. 8 h) by about $10 \%$ to $20 \%$ together with the underestimation of the downward shortwave radiation leads to a strong underestimation of the shortwave reflection in REMO-partial by up to $25 \%$ on 12 April (Fig. 8e). Here the problem is that the sea ice albedo in REMO is assumed to be between $55 \%$ for a surface temperature of $0^{\circ} \mathrm{C}$ and $75 \%$ for a surface temperature of $-10^{\circ} \mathrm{C}$ or below. In REMO-original at least the upper value of $75 \%$ is quite reasonable, because the value is representative for sea ice with leads, which are not explicitly considered in this version. In REMO-partial leads are explicitly considered to have an albedo of $7 \%$ leading to a lower average albedo. Thus the upper value should be higher than $75 \%$ in future simulations with REMOpartial since the aircraft observations show values up to $80 \%$ over sea ice. According to Lindsay and Rothrock (1994) even values up to $91 \%$ can appear. The lower value of $55 \%$ is also discussable because the sea ice albedo can fall well below this value in melting periods. Lindsay and Rothrock (1994) give a minimum value of $18 \%$. Another improvement would be the introduction of a water albedo dependent on solar zenith angle, although this only influences the reflected shortwave radiation because the sea surface temperature is prescribed.

In REMO-original the downward longwave radiation is underestimated on 14 April (Fig. 7f), and in REMOpartial it is overestimated on 10 and 12 April (Fig. 8f). As in the downward shortwave radiation, this difference is probably due to the increased moisture in REMOpartial. The upward longwave radiation is very well simulated in REMO-partial (Fig. 8g). On all days, ob- 
TABLE 2. Statistics of turbulent and radiation fluxes and surface temperature in the aircraft measurements compared with both REMO simulations (the turbulent heat fluxes are defined positive downward and negative upward).

\begin{tabular}{|c|c|c|c|c|}
\hline & \multicolumn{2}{|c|}{ REMO-original } & \multicolumn{2}{|c|}{ REMO-partial } \\
\hline & Aircraft & REMO & Aircraft & REMO \\
\hline \multicolumn{5}{|c|}{ Sensible heat flux $\left(\mathrm{W} \mathrm{m}^{-2}\right)$} \\
\hline Mean & -1.6 & -0.8 & 2.3 & -14.5 \\
\hline Std dev & 7.9 & 1.5 & 3.9 & 10.2 \\
\hline Bias & & 0.8 & & -16.8 \\
\hline Rmse & & 7.2 & & 19.1 \\
\hline Correlation & & 0.53 & & 0.51 \\
\hline \multicolumn{5}{|c|}{ Latent heat flux $\left(\mathrm{W} \mathrm{m}^{-2}\right)$} \\
\hline Mean & -3.6 & 0.0 & -1.3 & -8.9 \\
\hline Std dev & 4.9 & 0.1 & 1.8 & 3.9 \\
\hline Bias & & 3.6 & & -7.6 \\
\hline Rmse & & 6.0 & & 8.4 \\
\hline Correlation & & 0.25 & & 0.35 \\
\hline \multicolumn{5}{|c|}{ Momentum flux (Pa) } \\
\hline Mean & 0.21 & 0.13 & 0.18 & 0.13 \\
\hline Std dev & 0.09 & 0.05 & 0.08 & 0.05 \\
\hline Bias & & -0.08 & & -0.05 \\
\hline Rmse & & 0.10 & & 0.08 \\
\hline Correlation & & 0.68 & & 0.58 \\
\hline \multicolumn{5}{|c|}{ Downward shortwave radiation $\left(\mathrm{W} \mathrm{m}^{-2}\right)$} \\
\hline Mean & 246.5 & 262.8 & 259.7 & 244.0 \\
\hline Std dev & 38.9 & 22.6 & 30.2 & 24.1 \\
\hline Bias & & 16.3 & & -15.7 \\
\hline Rmse & & 35.5 & & 31.1 \\
\hline Correlation & & 0.58 & & 0.53 \\
\hline \multicolumn{5}{|c|}{ Shortwave reflection $\left(\mathrm{W} \mathrm{m} \mathrm{m}^{-2}\right)$} \\
\hline Mean & 188.7 & 197.1 & 205.0 & 166.6 \\
\hline Std dev & 39.3 & 17.0 & 30.1 & 18.7 \\
\hline Bias & & 8.4 & & -38.4 \\
\hline Rmse & & 38.8 & & 46.0 \\
\hline Correlation & & 0.30 & & 0.55 \\
\hline \multicolumn{5}{|c|}{ Downward longwave radiation $\left(\mathrm{W} \mathrm{m}^{-2}\right)$} \\
\hline Mean & 185.6 & 185.9 & 178.2 & 203.9 \\
\hline Std dev & 20.4 & 11.3 & 15.5 & 15.9 \\
\hline Bias & & 0.3 & & 25.7 \\
\hline Rmse & & 18.0 & & 30.4 \\
\hline Correlation & & 0.48 & & 0.47 \\
\hline \multicolumn{5}{|c|}{ Upward longwave radiation $\left(\mathrm{W} \mathrm{m}^{-2}\right.$ ) } \\
\hline Mean & 250.5 & 241.2 & 245.9 & 255.6 \\
\hline Std dev & 9.4 & 3.6 & 5.5 & 6.9 \\
\hline Bias & & -9.3 & & 9.7 \\
\hline Rmse & & 13.6 & & 12.1 \\
\hline Correlation & & 0.08 & & 0.33 \\
\hline \multicolumn{5}{|l|}{ Albedo $(\%)$} \\
\hline Mean & 76.2 & 75.0 & 78.9 & 68.2 \\
\hline Std dev & 8.0 & 0.0 & 6.2 & 2.1 \\
\hline Bias & & -1.2 & & -10.7 \\
\hline Rmse & & 8.1 & & 12.2 \\
\hline Correlation & & 0.15 & & 0.34 \\
\hline \multicolumn{5}{|c|}{ Surface temperature $\left({ }^{\circ} \mathrm{C}\right)$} \\
\hline Mean & 259.3 & 256.5 & 257.9 & 259.2 \\
\hline Std dev & 2.8 & 2.3 & 1.6 & 1.7 \\
\hline Bias & & -2.8 & & 1.3 \\
\hline Rmse & & 3.3 & & 2.2 \\
\hline Correlation & & 0.37 & & 0.77 \\
\hline
\end{tabular}

servations and this REMO simulation agree within the uncertainty of the observations. This is consistent with the realistically simulated surface temperature (Fig. 8i). Because of the lower surface temperature in REMOoriginal (Fig. 7i), the upward longwave radiation is also lower in this simulation (Table 2), although it still agrees with the observations within their uncertainty (Fig. $7 \mathrm{~g}$ ).

Even if the bias, rmse, and coefficient of correlation of the radiation fluxes do not show a clear improvement from REMO-original to REMO-partial (Table 2), the standard deviation in REMO-partial is much closer to the observations than the one in REMO-original. This shows that the spatial variability is better represented in REMO-partial compared with REMO-original. A more realistic description of the sea ice albedo and the sea ice concentration could further improve the simulation. The sea ice concentration gradient in REMOpartial is too weak. Therefore, the observed mean values of many parameters (turbulent heat fluxes, shortwave radiation fluxes, and downward longwave radiation) are between the two REMO simulations.

Despite the too low albedo, the surface temperature is represented well in REMO-partial. Here two compensating effects appear. Because observations are lacking, the thickness of sea ice is set to a constant value of $2 \mathrm{~m}$, which may be too much near the ice edge. The too low albedo would lead to too high surface temperatures, whereas a too thick ice cover reduces the conductive heat flux through the ice and thus leads to too low surface temperatures. Recent efforts to observe the sea ice thickness continuously in time and space with satellite laser measurements (Zwally et al. 2002) will help to reduce the error in ice thickness. Using the sea ice thickness measurements as a lower boundary will improve future simulations.

\section{c. Summary of the validation results}

It has been shown that the simulation of the surface temperature, the boundary layer temperature, and humidity has been clearly improved in the simulation with REMO-partial compared to REMO-original. All other investigated parameters do not show a pronounced improvement in the simulation of the mean values but in the spatial variability. The underestimation of the wind speed in both REMO-simulations will need further investigation. The comparison method with the condition of sea ice concentrations being more than $80 \%$ favors REMO-original because the grid cells and flight tracks with large differences in sea ice concentrations between airplane observations and the simulation are excluded from the comparison for REMO-original. REMO-partial shows a considerable improvement in the simulation of surface and boundary layer values compared with REMO-original. For global climate models with a much coarser resolution than the $18 \mathrm{~km}$ used in this regional climate model study, the improvement due to partial sea 
a)

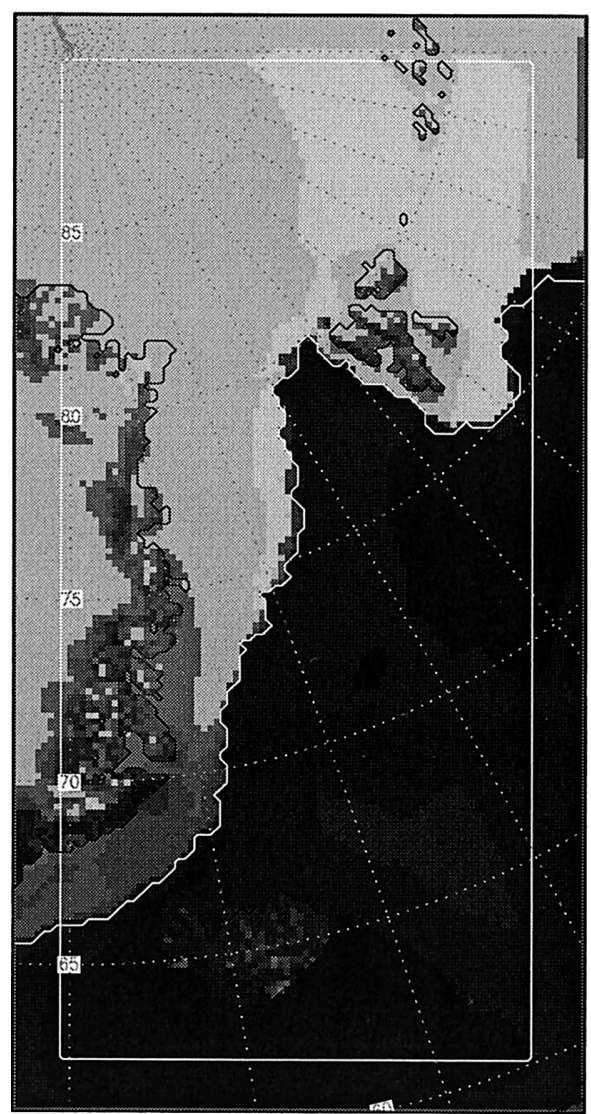

b)

FIG. 9. Surface latent heat flux $\left(\mathrm{W} \mathrm{m}^{-2}\right.$ ) in (a) REMO-original and (b) REMO-partial, averaged over the time period 0000 UTC 8 Apr to 0000 UTC 16 Apr 1999.

ice coverages in each grid cell should be even more pronounced.

From this study it cannot be concluded if the differences between REMO-original and REMO-partial are statistically significant because both simulations are only one representation of a possible state of the atmosphere. Ensemble simulations with both sea ice distributions would be necessary to consider the internal variability of the model and thus to calculate reliable significance levels of the differences. Because it has been shown that REMO is able to simulate the boundary layer near the ice edge reasonably well, it is possible to study the influence of the sea ice distribution on the boundary layer.

\section{Influences on the boundary layer}

In this section the influence of the sea ice cover on the boundary layer is investigated using the two REMO

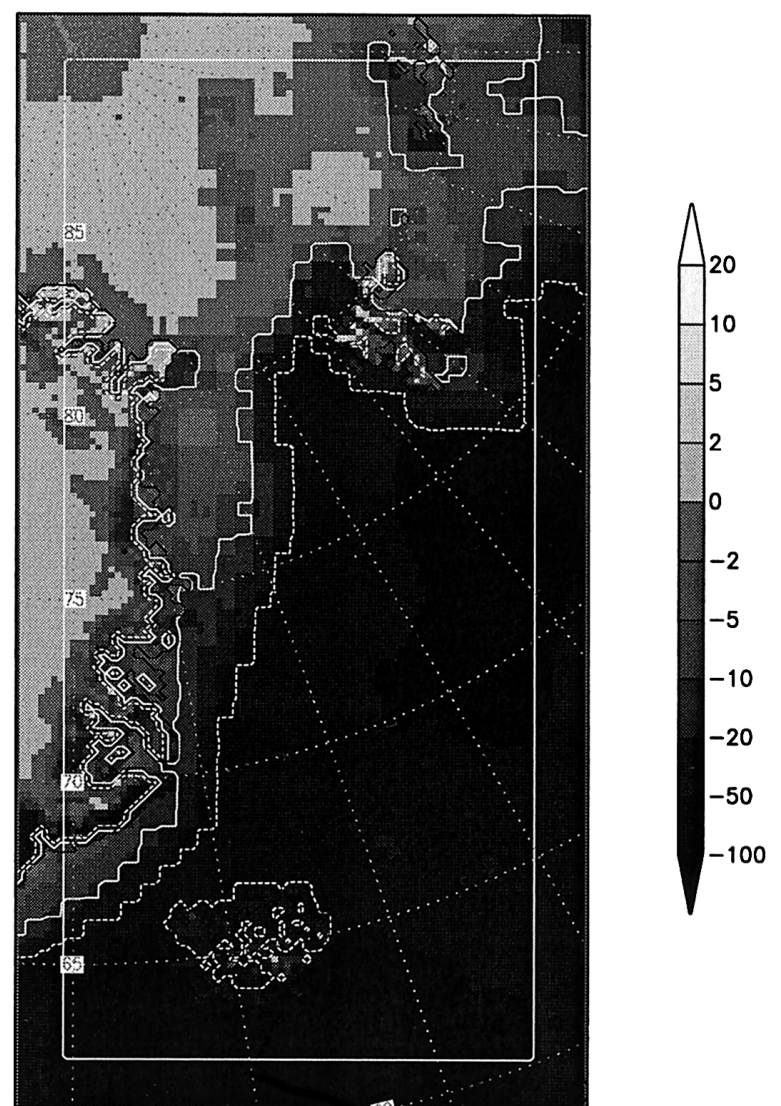

simulations. As shown in section 4 the sea ice distribution is more realistically prescribed from satellite data in REMO-partial than in REMO-original, where the ice edge is more pronounced than in reality (Fig. 2).

Because of the closed ice cover in REMO-original there are mainly downward turbulent heat fluxes over sea ice, whereas REMO-partial, considering leads and polynyas, often shows upward turbulent heat fluxes due to the relatively warm open water. The latent heat flux for both REMO simulations is shown as a time average for the time period from 8 to 16 April in Fig. 9. This is a period with high pressure over the central Arctic and northeasterly winds in the Fram Strait (Brümmer et al. 2000). The differences are very pronounced over Franz Josef Land $\left(81^{\circ} \mathrm{N}, 50^{\circ} \mathrm{E}\right.$, far northeast of Spitsbergen) and Northeast Water Polynyas $\left(81^{\circ} \mathrm{N}, 15^{\circ} \mathrm{W}\right.$, just northeast of Greenland), where the sea ice concentration in REMO-partial is only around $70 \%$ per grid cell compared with $100 \%$ in REMO-original. All in all the latent 
a)

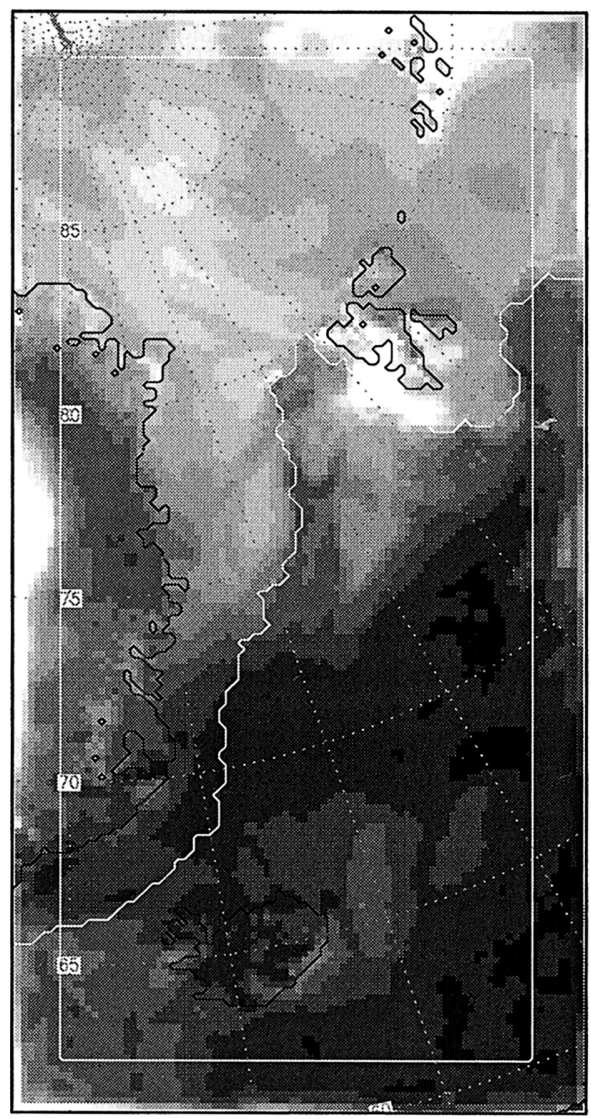

b)

FIG. 10. Total precipitation (mm) in (a) REMO-original and (b) REMO-partial for the time period 0000 UTC 8 Apr to 0000 UTC 16 Apr 1999.

heat flux is upward over large areas of the ice when using REMO-partial (Fig. 9b), while it is mostly downward in REMO-original (Fig. 9a).

The differences in latent heat fluxes are reflected by differences in the total cloud cover (not shown) and precipitation (Fig. 10). Total cloud cover and precipitation are larger in (b) REMO-partial than (a) REMOoriginal because the amount of water transported into the atmosphere is larger. In weather situations with missing cyclone activity the differences are only due to the enhanced evaporation over the polynyas in REMO-partial compared with REMO-original, which leads to more moisture in the atmosphere and thus to more convection and precipitation. In cases with cyclone activity, other effects, like a slightly different position of the cyclone, can cause even more changes in cloud cover and precipitation.

The gradients in the surface temperature are larger in REMO-original compared to REMO-partial near the ice

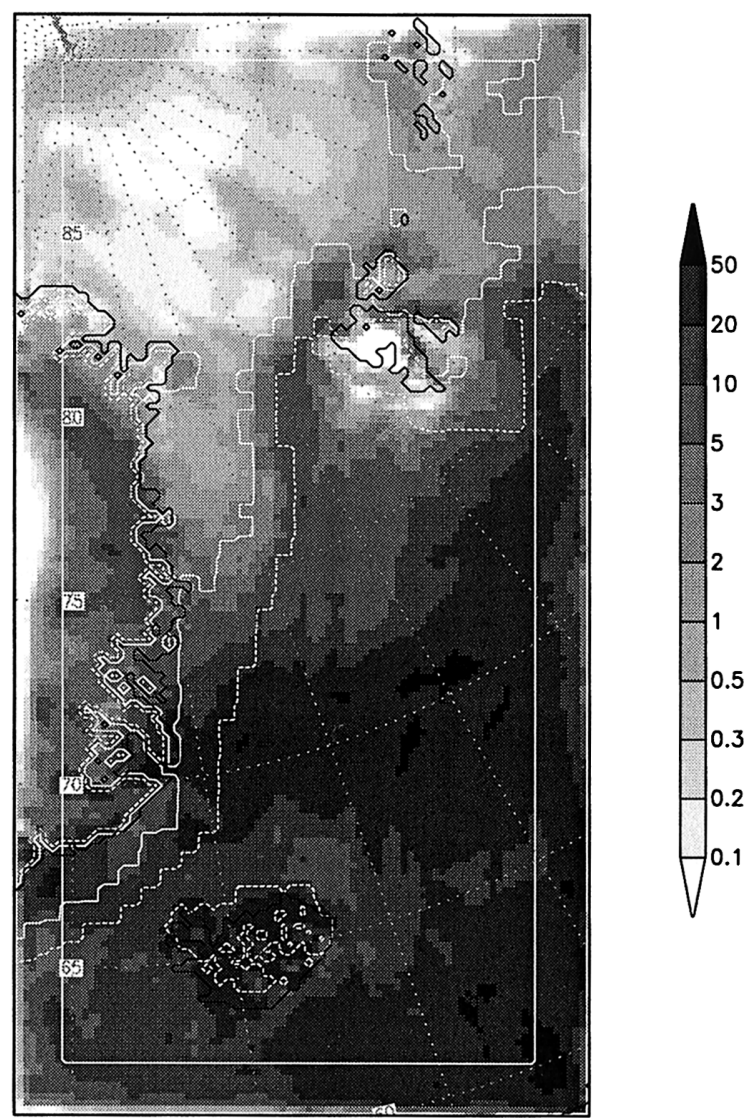

edge (not shown) because of the sharp ice edge in REMO-original. Since the cyclone is situated north of the ice edge northwest of Spitsbergen at 20 April (Fig. 3 ), there is an off-ice wind east of Greenland. This leads to more intense upward-directed sensible and latent heat fluxes over the open water near the ice edge in REMOoriginal (Fig. 11a) compared with REMO-partial on this day (Fig. 11b). Over sea ice the upward fluxes of REMO-partial are much larger, as has already been shown for the average values (Fig. 9).

The sea ice distribution can also influence the genesis and development of cyclones. Figure 3 shows slightly different cyclone tracks and minimum pressures in the two REMO simulations, although the differences between both REMO simulations and the ECMWF analysis are much larger. Over water the low pressure system is more pronounced in REMO-partial than in REMOoriginal, whereas over sea ice it tends to be less pronounced. A secondary pressure minimum is developing 
a)

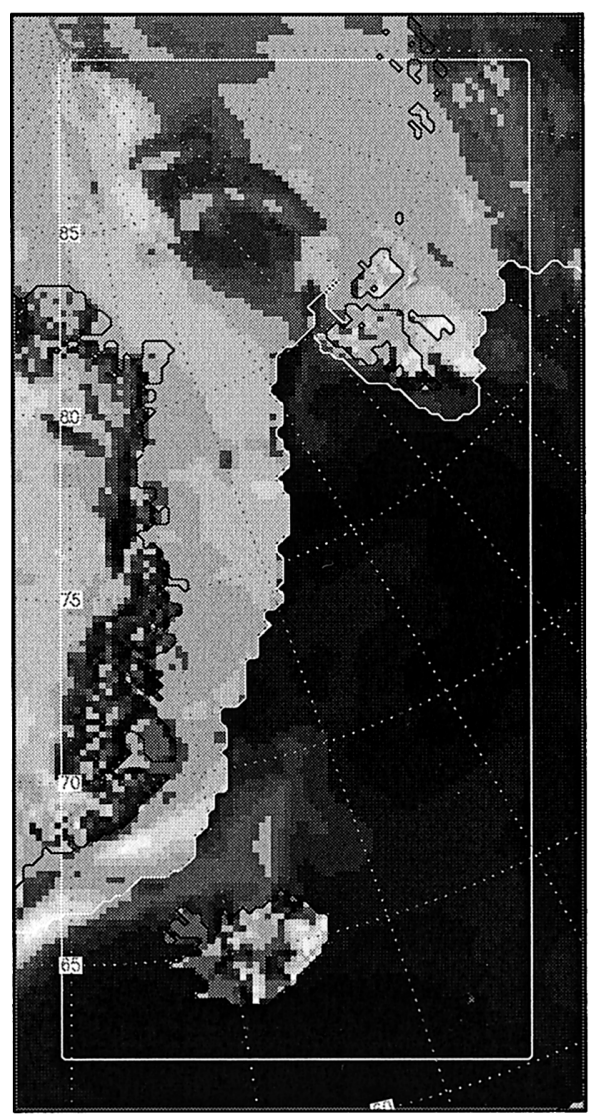

b)

FIG. 11. Surface latent heat flux $\left(\mathrm{W} \mathrm{m}^{-2}\right)$ in (a) REMO-original and (b) REMO-partial, averaged over the time period 0500-0600 UTC 20 Apr 1999.

in both REMO simulations near the ice edge in the region of off-ice wind but is not present in the ECMWF analysis (Fig. 12). All in all the influence of different sea ice distributions on the development of the cyclone is small compared with the differences between the ECMWF analysis and both REMO simulations in this case study.

The results show on the one hand the importance of prescribing the sea ice cover realistically to get reasonable results with a regional climate model. On the other hand, the influence of the sea ice distribution on mesoscale meteorological phenomena in cold regions becomes clear once more. The boundary layer can react very sensitively to changes in the sea ice distribution. It should now be investigated using ensemble simulations and additional case studies whether the sea ice distribution may also influence the genesis and development of cyclones, which could be important for weather and climate not only in the Arctic region.

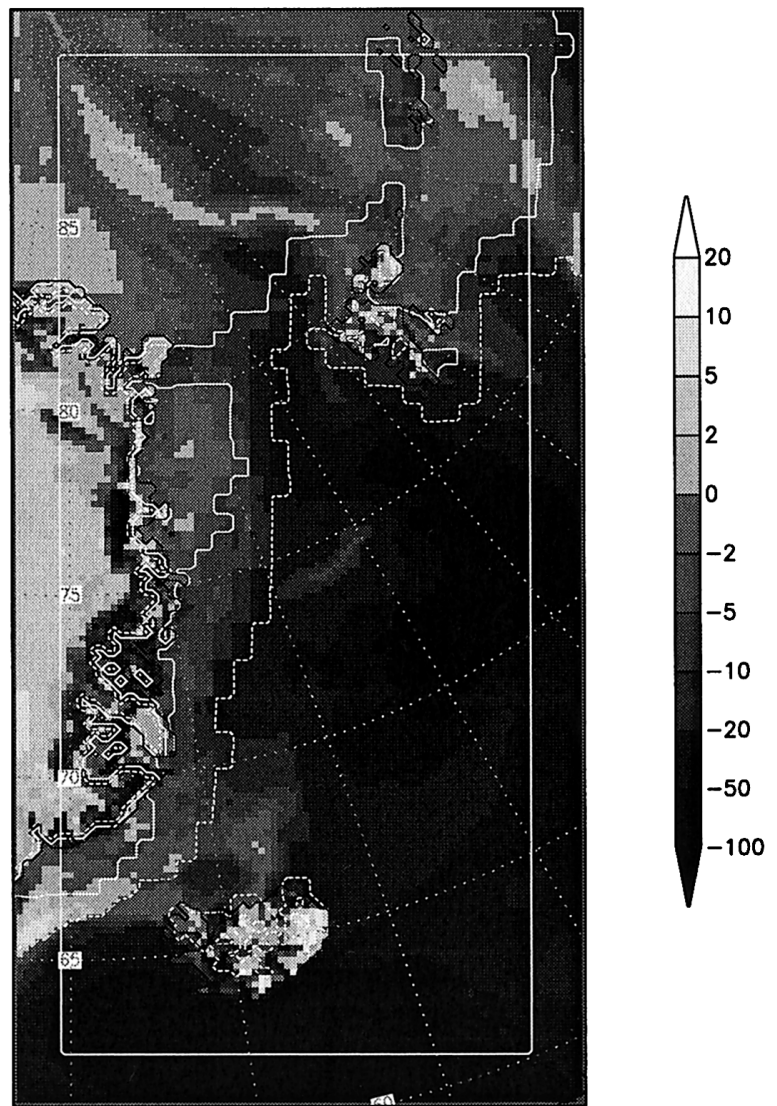

\section{Conclusions}

The observation data of the FRAMZY field campaign offer a good opportunity to validate REMO results at the ice edge and in the boundary layer. The FRAMZY field campaign created data for 5 days with different meteorological situations (north/northeast flow almost parallel to the ice edge, convergence near the ice edge, weak pressure gradients within a high pressure system, strong northeast flow in the northwest sector of a northward-moving Fram Strait cyclone, cyclone north of the ice edge) that are of great value for model validation.

The comparison of the results of two different REMO simulations with observations from the FRAMZY field campaign has shown the importance of realistically prescribing the sea ice distribution for the quality of the simulation of the surface temperature, boundary layer temperature, and specific humidity. In REMO-partial, where each grid cell can be partly covered by sea ice 
a)

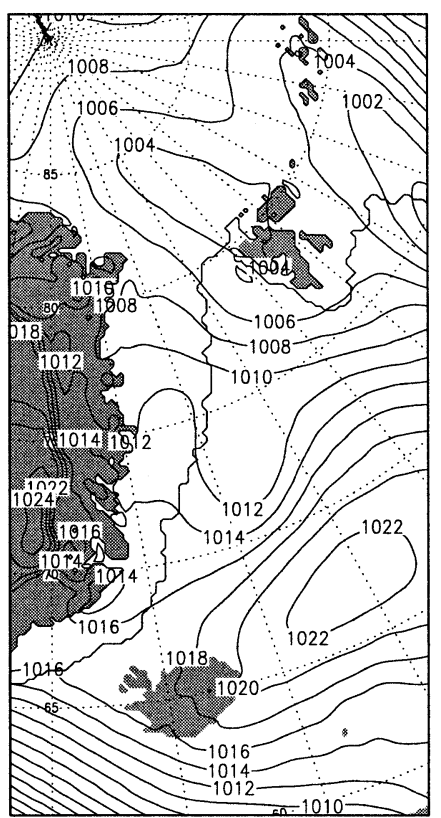

b)

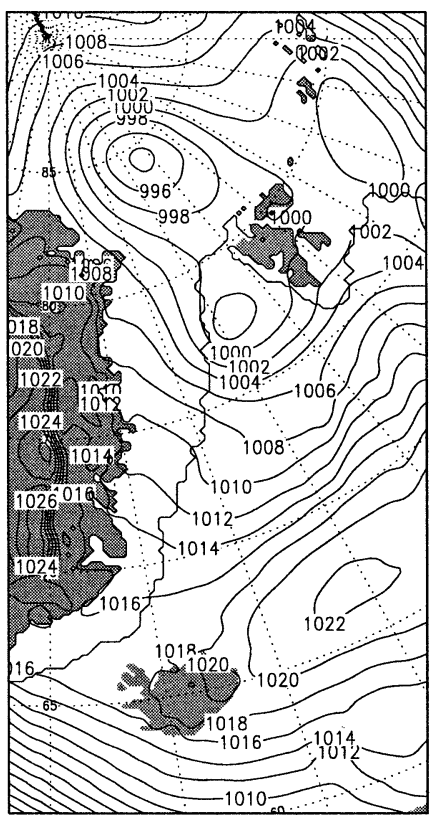

c)

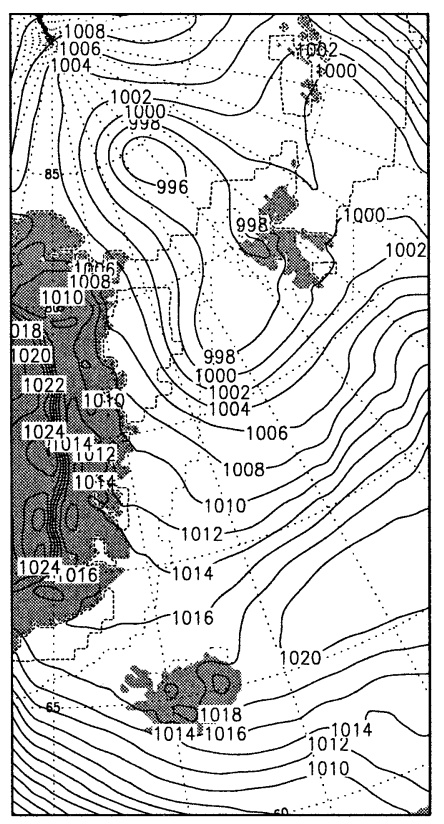

FIG. 12. Sea level pressure (hPa) in (a) the ECMWF analyses, (b) REMO-original, and (c) REMO-partial for 0600 UTC 20 Apr 1999.

and where the sea ice distribution is prescribed from satellite data, the bias and rmse of temperature and specific humidity are reduced by more than $50 \%$, and the coefficient of correlation is improved compared with REMO-original, where each grid cell is either completely free of ice or completely covered by ice, and the sea ice distribution is diagnosed from the surface temperature.

No clear improvement in the mean values of the boundary layer wind speed, the turbulent heat fluxes, and the radiation fluxes could be shown in REMO-partial compared with REMO-original, but the variability of all parameters is more realistically simulated in REMO-partial.

The mean values of specific humidity and the shortwave and longwave radiation components are simulated very well with both REMO versions. The differences between measured and simulated specific humidity and radiation fluxes are in most cases smaller than the errors of the measurements. Only the shortwave reflection in REMO-partial is underestimated by about $10 \%$ to $20 \%$ because of a too small albedo. To solve this problem, the admitted sea ice albedo range from 55\% to $75 \%$ in REMO should be extended, because the sea ice albedo can rise well above and fall well below this range. A problem that still needs to be investigated is the systematic underestimation of the wind speed over ice in the boundary layer by about $25 \%$. Therefore the determination of the surface roughness length should be an item of further model development.
REMO gives additional meteorological information on mesoscale phenomena, which cannot be retrieved from global analyses or climate models because of their coarser resolution. Pressure and atmospheric temperature gradients get more pronounced in both REMO versions compared with the ECMWF analysis. In both REMO versions a secondary cyclone is developing near the ice edge in a region of off-ice wind that is not present in the ECMWF analysis. Impacts of leads and polynyas within the ice can only be studied with REMO-partial. Whereas the closed sea ice cover in REMO-original leads to mostly downward turbulent heat fluxes, the heat fluxes in REMO-partial are often directed upward because of leads and polynyas. Because the heat fluxes can influence cloud cover and precipitation as well as the development of cyclones, it is important to prescribe a realistic sea ice distribution in model studies. Since the sea ice distribution may influence the weather development, this could also be of relevance for weather forecasting.

Acknowledgments. Constructive comments of the reviewers are appreciated. We would like to thank Dr. G. Müller, Mr. D. Schröder, and Prof. B. Brümmer for the preparation of the data from aircraft measurements and them as well as Dr. S. Dierer for fruitful discussions about data quality and comparison methods. This work has been supported by the Deutsche Forschungsgemeinschaft (DFG) within SFB 512, "Cyclones and the North Atlantic Climate System.” 


\section{REFERENCES}

Avissar, R., and R. A. Pielke, 1989: A parameterization of heterogeneous land surfaces for atmospheric numerical models and its impact on regional meteorology. Mon. Wea. Rev., 117, 2113 2136.

Bougeault, P., 1983: A non-reflective upper boundary condition for limited-height hydrostatic models. Mon. Wea. Rev., 111, 420429.

Brümmer, B., Coauthors, 2000: Field Experiment FRAMZY 1999. Cyclones over the Fram Strait and their impact on sea ice: Field report with examples and measurements. Berichte aus dem Zentrum für Meeres- und Klimaforschung, Reihe A: Meteorologie, No. 33, Zentrum für Meeres- und Klimaforschung der Universität Hamburg, Meteorologisches Institut, Germany, 176 pp.

— G. Müller, B. Affeld, R. Gerdes, M. Karcher, and F. Kauker, 2001: Cyclones over the Fram Strait: Impact on sea ice and variability. Polar Res., 20, 147-152.

Burk, S. D., R. W. Fett, and R. E. Englebretson, 1997: Numerical simulation of cloud plumes emanating from Arctic leads. J. Geophys. Res., 102 (D14), 16 529-16 544.

Cavalieri, D. J., and Coauthors, 1992: NASA sea ice validation program for the DMSP SSM/I: Final report. NASA Tech. Memo. 104559, 126 pp.

Fouquart, Y., and B. Bonnel, 1980: Computations of solar heating of the earth's atmosphere: A new parameterization. Beitr. Phys. Atmos., 53, 35-62.

Glendening, J. W., and S. D. Burk, 1992: Turbulent transport from an Arctic lead: A large eddy simulation. Bound.-Layer Meteor., 59, 315-339.

Grønås, S., and N. G. Kvamstø, 1995: Numerical simulations of the synoptic conditions and development of Arctic outbreak polar lows. Tellus, 47A, 797-814.

Gultepe, I., G. A. Isaac, A. Williams, D. Marcotte, and K. B. Strawbridge, 2003: Turbulent heat fluxes over leads and polynyas, and their effects on Arctic clouds during FIRE.ACE: Aircraft observations for April 1998. Atmos.-Ocean, 41, 15-34.

Hagemann, S., M. Botzet, L. Dümenil, and B. Machenhauer, 1999 Derivation of global GCM boundary conditions from $1 \mathrm{~km}$ land use satellite data. Rep. 289, Max-Planck-Institut für Meteorologie, Hamburg, Germany, 34 pp.

Hennemuth, B., and D. Jacob, 2002: Surface heat fluxes over the Baltic Sea. Meteor. Z., 11, 105-118.

Jacob, D., 2001: A note to the simulation of the annual and interannual variability of the water budget over the Baltic Sea drainage basin Meteor. Atmos. Phys., 77, 61-73.

— , and R. Podzun, 1997: Sensitivity studies with the Regional Climate Model REMO. Meteor. Atmos. Phys., 63, 119-129.

_- and Coauthors, 2001: A comprehensive model intercomparison study investigating the water budget during the BALTEX-PIDCAP period. Meteor. Atmos. Phys., 77, 19-43.

Katzfey, J. J., 1999: Storm tracks in regional climate simulations: Verification and changes with doubled $\mathrm{CO}_{2}$. Tellus, 51A, 803814.

Klemp, J. B., and D. R. Durran, 1983: An upper boundary condition permitting internal gravity wave radiation in numerical mesoscale models. Mon. Wea. Rev., 111, 430-444.

Lindsay, R. W., and D. A. Rothrock, 1994: Arctic sea-ice albedo from AVHRR. J. Climate, 7, 1737-1749.

Mailhot, J., A. Tremblay, S. Belair, I. Gultepe and G. A. Isaac, 2002 : Mesoscale simulation of surface fluxes and boundary layer clouds associated with a Beaufort Sea polynya. J. Geophys. Res., 107, 8031, doi:10.1029/2000JC000429.

Majewski, D., 1991: The Europa-Modell of the Deutscher Wetterdienst. Proc. Seminar on Numerical Methods in Atmospheric Models, Vol. 2, Reading, United Kingdom, ECMWF, 147-191. and Coauthors, 1995: Dokumentation des EM/DM-Systems. Abteilung Forschung, Deutscher Wetterdienst, Offenbach, Germany, 534 pp.

Morcrette, J.-J., and Y. Fouquart, 1986: Pressure and temperature dependence of the absorption in longwave radiation parameterizations. Beitr. Phys. Atmos., 59, 455-469.

Nordeng, T. E., 1994: Extended versions of the convection parametrization scheme at ECMWF and their impact upon the mean climate and transient activity of the model in the Tropics. Research Department Tech. Memo. 206, ECMWF, Shinfield Park, Reading, Berkshire, United Kingdom, 41 pp.

Repina, I. A., and A. S. Smirnov, 2000: Heat and momentum exchange between the atmosphere and ice from the observational data obtained in the region of Franz Josef Land. Izu. Atmos. Oceanic Phys., 36, 618-626.

Rinke, A., and K. Dethloff, 2000: On the sensitivity of a regional Arctic climate model to initial and boundary conditions. Climate Res., 14, 101-113.

Roeckner, E., and Coauthors, 1996: The atmospheric general circulation model ECHAM-4: Model description and simulation of present-day-climate. Max-Planck-Institut für Meteorologie Rep. 218, Hamburg, Germany, 90 pp.

Simmonds, I., and W. F. Budd, 1991: Sensitivity of the Southern Hemisphere circulation to leads in the Antarctic pack ice. Quart. J. Roy. Meteor. Soc., 117, 1003-1024.

Simmons, A. J., and D. M. Burridge, 1981: An energy and angularmomentum conserving vertical finite-difference scheme and hybride vertical coordinate. Mon. Wea. Rev., 109, 758-766.

Tiedtke, M., 1989: A comprehensive mass flux scheme for cumulus parameterization in large-scale models. Mon. Wea. Rev., 117, 1779-1800

USGS-NASA, cited 2002: GTOPO30 documentation. USGS-NASA Distributed Archive Center. [Available online at http:// edcdaac.usgs.gov/gtopo30/README.html.]

von Salzen, K., M. Claussen, and K. H. Schlünzen, 1996: Application of the concept of blending height to the calculation of surface fluxes in a mesoscale model. Meteor. Z., N.F.5, 60-66.

Walsh, K. J. E., and J. J. Katzfey, 2000: The impact of climate change on the poleward movement of tropical cyclone-like vortices in a regional climate model. J. Climate, 13, 1116-1132.

Zwally, H. J., and Coauthors, 2002: ICESat's laser measurements of polar ice, atmosphere, ocean, and land. J. Geodyn., 34, 405445. 